\title{
わが国の未来を拓く科学技術政策
}

\author{
井村裕夫1,2
}

\begin{abstract}
著者抄録 : 1980年代以降日本を取り巻く環境は大きく変わった。重工業から知的産業にシフトし， 今や経済が知識によって, 科学技術によって駆動される時代になっている。1996年に第一期の科 学技術基本計画が策定され, 日本の科学技術予算が急速な伸びを示した。2001年に入り, 行政改 革に伴って科学技術会議は総合科学技術会議に再編され第二期の科学技術基本計画が策定され た。同計画の2本の柱は, 科学技術の4重点分野, ライフサイエンス, 情報通信, 環境, ナノテク ノロジー・材料の設定と, 科学技術研究開発システムの改革とである。産学連携, 自由な発想に よる研究の尊重, 国際的な競争力の育成, 若手研究者および科学技術教育が課題となっている。重 点分野のうちのライフサイエンスに関して, ポストゲノム研究, ポストジェノミックスの研究に ついて言及した。
\end{abstract}

キーワード：日本, 科学技術政策, 総合科学技術会議, 科学技術基本計画, 研究開発システム, 研究開発, 産学共同, ポストゲノム, ポストゲノミックス, ライフサイエンス, 情報通信, 環境, ナノテクノロジー

\section{Japan's science and technology policy exploiting the future}

\section{IMURA Hiroo, 1,2}

Author Abstract: Since the eighties environment surrounding Japan has been drastically changing. Everybody finds that the nation' economy is driven by knowledge or science and technology at the current age. In 1996 the Japanese Government formulated the first Science and Technology Basic Plan resulting in that nation's budget allocated to science and technology has increased rapidly. Entering the year of 2001 Council for Science and Technology was reorganized as Council for Science and Technology Policy due to administrative reform the Government has proceeded. Then the Second Science and Technology Basic Plan was formulated. The main two items of this Plan are 1) to set four emphasized science and technology areas; life science, information and telecommunications, environment and nano-technology materials, and 2) to reform the current science and technology R \& D systems. For the latter several issues are raised including industry-academia collaboration, researches with flexible and free idea, fostering of international R \& D competitiveness, and training or fostering of young scholars, and science and technology education for the juveniles. The speaker also talked over post-genome age, and post-genomics researches.

Key words: Japan, science and technology policy, Council for Science and Technology Policy, Science and Technology Basic Plan, research and development system, R \& D, industry-academia collaboration, post-genome, post-genomics, life science, information and telecommunications, environment, nano-technology

\footnotetext{
1総合科学技術会議議員（†100-8970 東京都千代田区霞ヶ関3-1-1） Tel. 03(3581)9796

${ }^{1}$ Science and Technology Policy (1-1, Kasumigaseki 3-chome, Chiyoda-ku, Tokyo, 100-8970)

2京都大学名誉教授

${ }^{2}$ Kyoto University Emeritus Professor
} 
「わが国の未来を拓く科学技術政策」という少し 大きな課題を取り上げましたが, 本日は日本の科学 技術政策としてどのようなことが問題になってい るのかをお話ししたいと考えています。

科学技術が政策の重要な課題になったのは, 第二 次世界大戦中ではないかと思います。第二次世界大 戦は, 参加したすべての国にとって総力戦で, 当 然, 科学者も戦争のために動員され, その中で特に 有名なのが, アメリカで物理学者が原爆を開発した ということではないかと思います。

戦争が終わる1年ほど前に, 勝利を確信したアメ リカのルーズベルト大統領は, 戦後の科学技術政策 のあり方について諮問しました。バーネバー・ブッ シューこれはMITの学部長から戦争中に国防省の 部長に異動した人で, およそ1年をかけて, わが国 の敗戦の1か月ほど前に, トルーマン大統領に報告 したのが, 有名な「科学: その終わりなきフロン ティア（The Science: The Endless Frontier）」という 仮題をつけた報告書です。この報告書の中でブッ シュは,「科学は戦後もどんどんと発達していくで あろう。それを国家の社会あるいは経済のために活 用していくべきであり, 政府は科学を支援すべきで ある」ということを述べています。

これを受けて，1950年に全米科学財団（National Science Foundation）が設立されました。これは財団 と訳していますが, 政府機関で, 以後, 今日までア メリカの基礎科学を支えてきたわけです。同時に, National Institute of Healthというのがありましたが, これを大幅に拡充いたしました。これらが, 現在, アメリカの科学技術を支えるうえで, 大変大きな役 割を果たしてきたと思います。

わが国は, 第二次世界大戦の敗戦により，国土は 焦土と化しました。その中から立ち上がるために は, 科学技術が非常に重要であるということで, 1956年に科学技術庁が発足しましたし, 59年には科 学技術会議が設立されました。1960年代からわが国 の経済の高度成長が始まりました。そして，1980年 代には, いわゆるバブル景気という空前の好景気が 訪れたのであります。その空前の好景気の中で, 科 学技術にも高等教育にも余り投資がなされなかっ たということは, 大変深刻な問題で, このことが現 在のわが国の困難な状況の1つの原因になっている のではなかろうかと, 私は考えています。

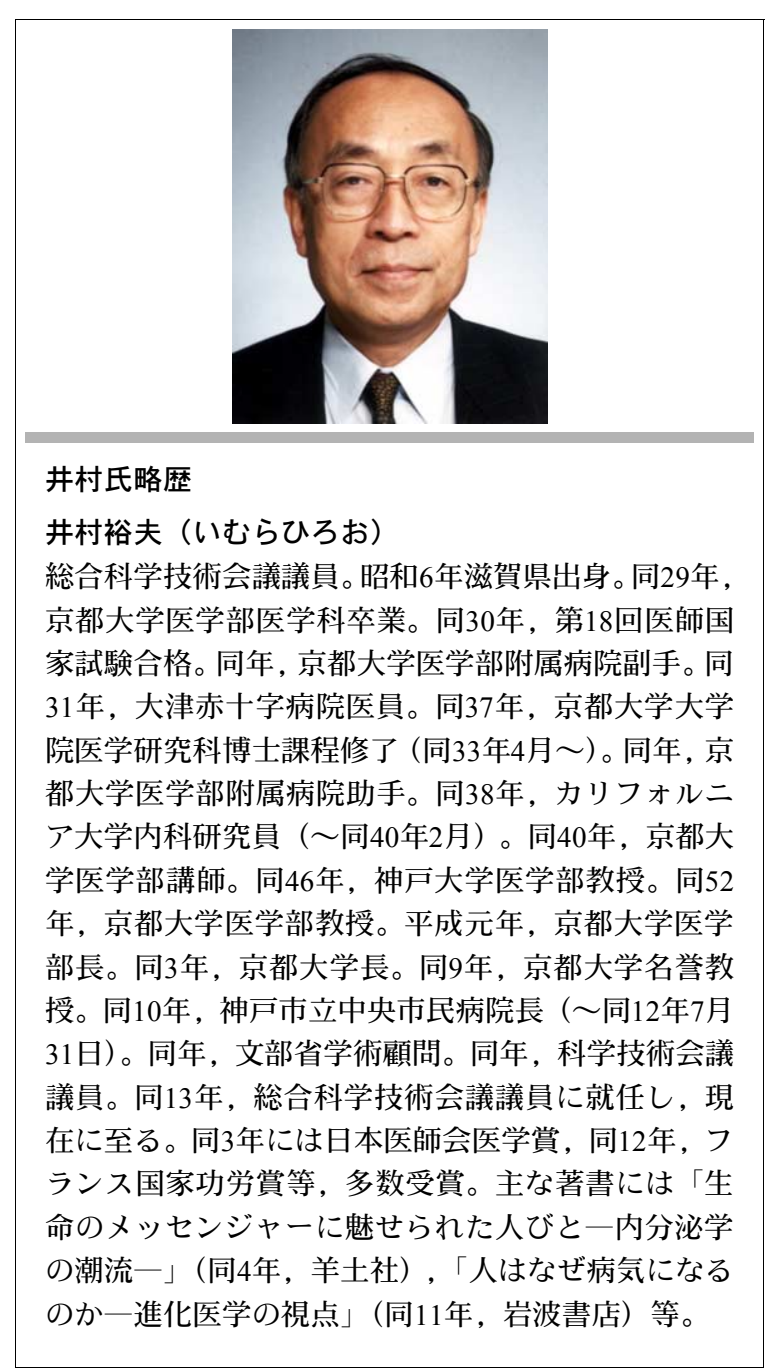

\section{大きく变わった環境}

1980年代,「ジャパン・アズ・ナンバーワン」と 呼ばれて喜んでいるときに,すでにわが国を取り巻 く環境は大きく変わっていました。

1つは, 戦後のわが国の科学技術は, 欧米から技 術を導入して,それをわが国でより洗練されたもの として,いい製品を作るということで発展してきた わけです。しかし, 賃金がどんどんと上がってきま すと, 技術導入型では立ち行かなくなり, フロント ランナー型に転換する必要に迫られてきました。

第2番目は, 重工業から知的産業に変わってきた ということです。1985年にオックスフォードに学会 で行ったところ, 街を歩いていると本屋に日本語を 書いた雑誌があったのを見つけました。それは「重 
厚長大 軽薄短小」と書いてあった。手に取ってみ ると, 日本の産業が重厚長大産業から家電製品等の 軽薄短小産業に変わりつつあるということを紹介 したものでした。その後, ご承知のように, IT, バ イオテクノロジーなど, より知的な産業に変わって きたわけです。

1980年代から次第に国際競争が激化して, メガコ ンペティションと呼ばれる経済競争が起こってき ました。その中で, わが国は取り残された感がある と思う。このメガコンペティションは世界にさまざ まな貧富の格差を生じており, これが今世紀の大き な問題になるのではないかと思います。

さらに, 1970年代から, 人間の活動範囲の増加, あるいは人口の増加などにより, 環境問題が非常に 大きな課題になってきました。ローマクラブが有名 な「成長の限界」を発表しましたが, その後, 我々 はその警告に対して十分対応できない状況のまま です。

このように, 急速な変化により, 今や経済が知識 によって, 科学技術によって駆動される時代になっ ています。
その一例を示したいと思います。それはサイエン ス・リンケージと呼ばれるものです。サイエンス・ リンケージというのは, 1つの特許に平均していく つの論文が引用されているかという数を示したも ので, これが高いほど, サイエンス・ベースの特許 になると思います。アメリカでは, 1980年代からま ず情報通信分野（図1）で，さらに，1990年代に入 りますと, バイオサイエンス, ライフサイエンス （図2）の分野で急速にサイエンス・リンケージが増 えています。しかし, わが国はまだかなり低い状況 のままです。ヨーロッパは, 大体この中間であると 考えていただいてよいと思います。

このような環境の変化に対応するために, わが国 においても，1995年に議員立法で, 科学技術基本法 が作られました。それを受けて，1996年には第1期 の科学技術基本計画が策定され，これによってわが 国の科学技術予算が急速な伸びを示し, 2001年にな りますと, 行政改革に伴って, 科学技術会議は総合 科学技術会議に再編され, また, 第2期の科学技術 基本計画が策定されました。

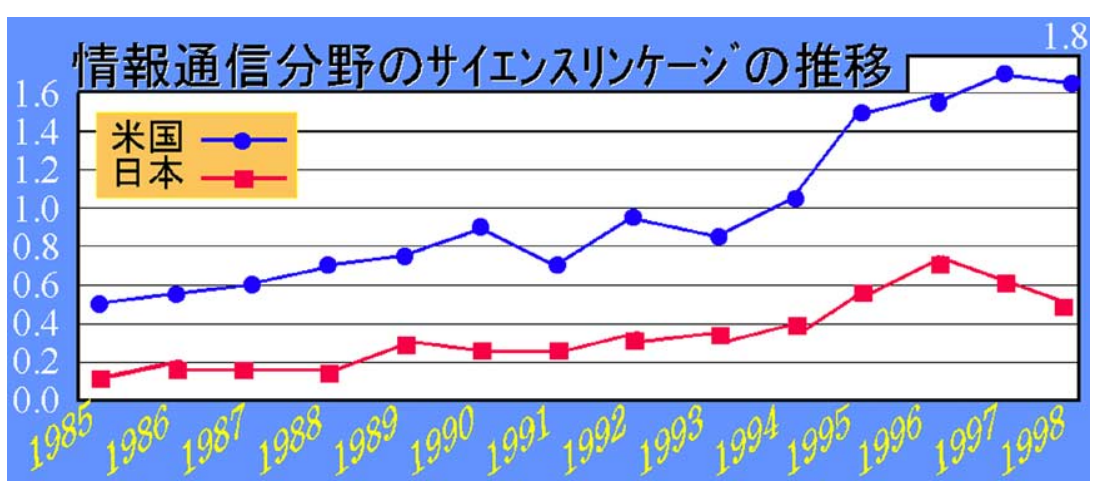

図1

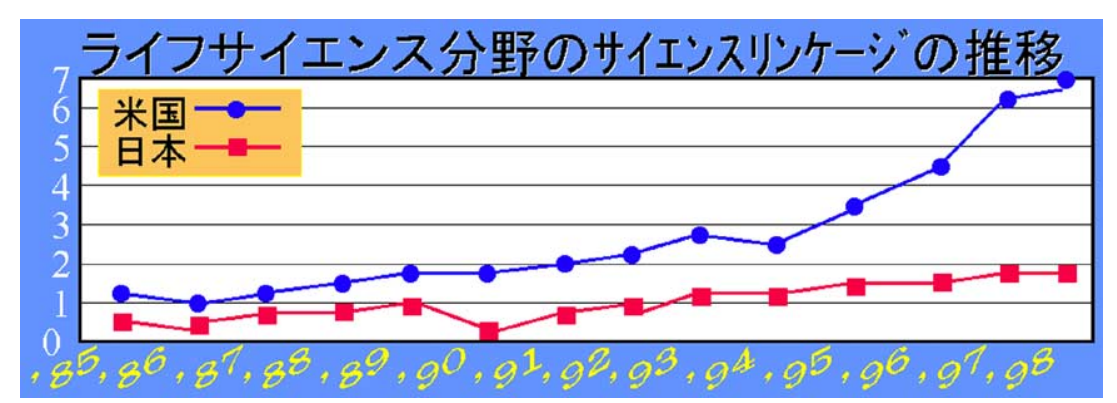

図2 


\section{総合科学技術会議}

総合科学技術会議というのは,わが国の科学技術 政策の立案, 実施をする。従来は総理の諮問に応じ て答申することになっていたが, 自ら意見を言うこ ともできるようになっています。さらに, 重要政策 の評価, 各省の枠を超えた政策の実施, 科学技術に 関する情報の収集と分析などを課題としており, 総 理を議長とする会合を月1回開催するとともに, 専 門調査会を設けてさまざまな課題について検討を しているところです。

この総合科学技術会議が最初に行った仕事が, 2001年度から5年間の科学技術基本計画です。この 基本計画は大きく2つの政策の柱からなっていま す。

その第1は, 科学技術の戦略的重点化で, 研究者 の自由な発想による研究は,これを今後とも一層推 進していこうということです。しかし，国家的・社 会的課題に対応した研究は思い切って重点化をす るということに決め, 重点4分野として, ライフサ イエンス, 情報通信, 環境, ナノテクノロジー・材
料という4つを選びました。

これを選ぶにあたって,さまざまな研究分野の科 学的なインパクトと社会的・経済的インパクト（図 3）を評価してもらいました。丸が大きいところは わが国が進んでいるもの, 丸が小さいのはわが国が 後れているところであります。

例えば, ライフサイエンスの分野で13と書いてい るのは臨床医学で, 臨床医学は社会・経済インパク トも科学インパクトも高いが, わが国は必ずしも十 分進んでいないということになる。12は脳科学で, 脳科学は科学的インパクトは非常に大きいが, 社 会・経済インパクトはそれほど大きくないというこ とになる。情報通信では，23はネットワークです が,これはわが国がかなり進んでいるが, 社会的 . 経済的インパクトも, 科学インパクトも非常に大き いということです。

こういった点をプロットして, 最終的にはライフ サイエンス, 情報通信, 環境, ナノテクノロジー・ 材料の4分野を, 日本が必ずしも進んでいないけれ ども, 社会的・経済的インパクトも科学的インパク トも大きいので, 選んでいこうということにしまし

\section{今後の科学技術の重点化の方向 (3軸による評価)}

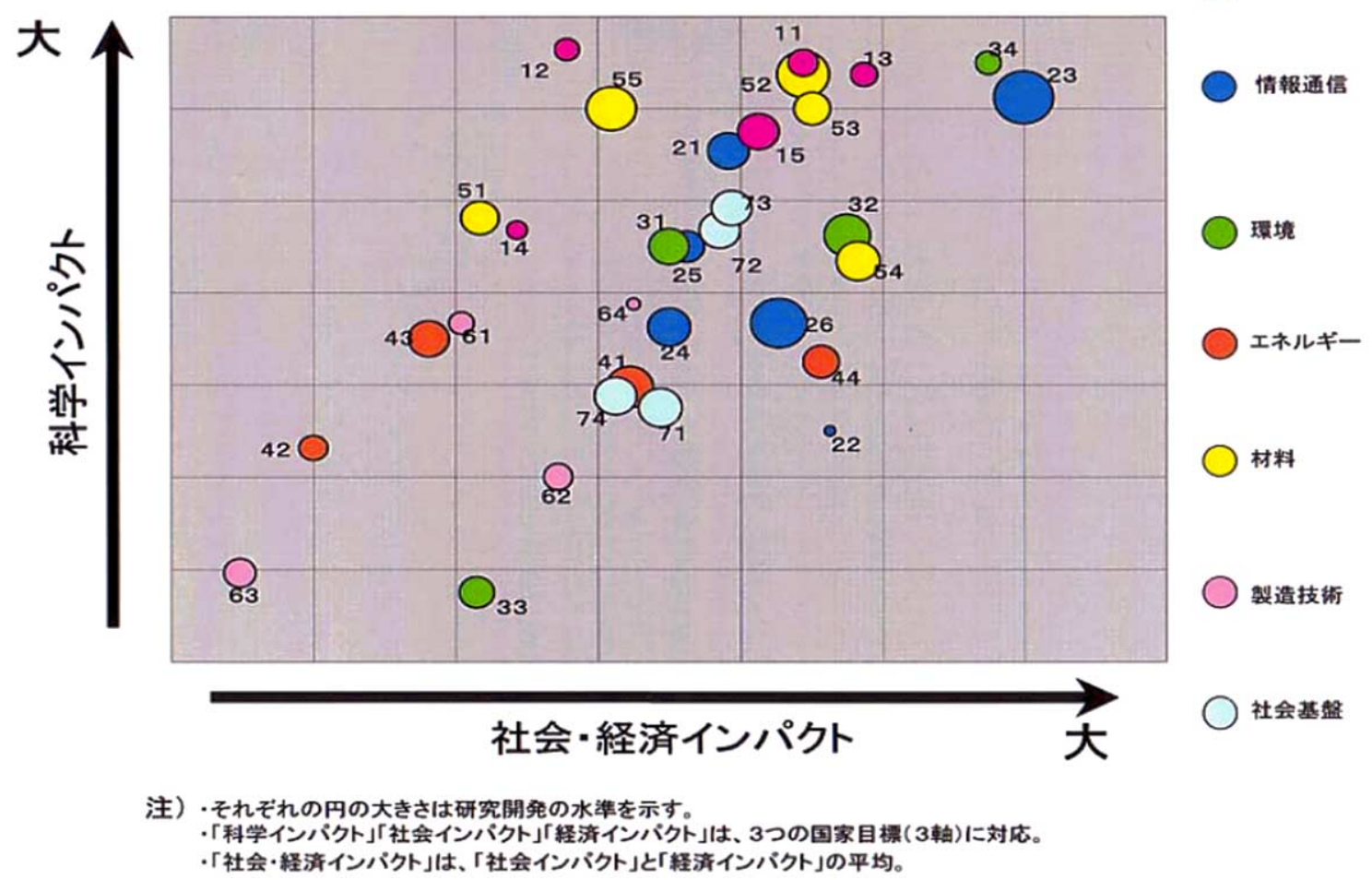


た。さらに, その基盤を支えるものとして, エネル ギー, 製造技術, 社会基盤, 宇宙などを取り上げた わけです。

\section{ポストゲノム研究の時代}

ライフサイエンスがなぜ重要であるのかという と, それはわが国が急速に高歯化社会を迎えてい ることと無関係ではありません。わが国は世界で 類をみないほど顕著な高齢化社会を迎えているわ けです。

このような高齢化社会においては, 健康寿命, あ るいは活動的平均寿命というのが重要になります。 平均寿命の中で, その人が人の世話にならないでど れだけ生きられるかということです。学問的には活 動的平均寿命という言葉がよく使われます。これは 仙台の調査で, 例えば, 65歳の人をとりますと, 65 歳以降, 男性は平均 16.1 年, 女性は平均 20.4 年生き られるわけです。しかし, その中で人のお世話にな らないといけない期間が, 男性は 1.4 年, 女性は 2.7 年, 平均してあります。この期間をいかに短くする かということが, 高齢化社会にとっては大変重要な 課題であり, これを半分にすると, 年間の健康保険 の費用がおよそ3兆円節約できるという予想も立て られています。

これからの重要な病気としては, 高龄化に伴って 多くなる, がん, 脳血管障害, 心蔵疾患, これらの もとになる糖尿病, 高血圧, 高脂血症, それから老 人性痴呆, 骨粗しょう症といったものが重要になり ます。こういった病気に対応するために, まず基礎 的な研究から積み上げていくということが, 現在で は非常に重要です。

ご承知のように, 2001年という年は, 人間の設計 四ともいうべきゲノムの配列がおよそ確定した年 になりました。これは科学の歴史の中で特筆すべき 大きなことです。

我々の遺伝子（図4）は, 二重らせん構造を持っ ていて, $\mathrm{G}, \mathrm{C}, \mathrm{T}, \mathrm{A}$ と呼ばれる4種類の塩基から できています。TはAと, $\mathrm{G}$ はC と結びついて, 二本 鎖を作っているわけですが, 我々の体の中にはおよ そ30億一正確には32億と推定されているが一の塩 基対があるわけです。

この中で実際にたんぱくを作って機能を発揮す る遺伝子がいくつあるのかということは, まだよく わかっていませんが, およそ3万から4万と推定され ています。現在ヒト以外にショウジョウバエ, 線

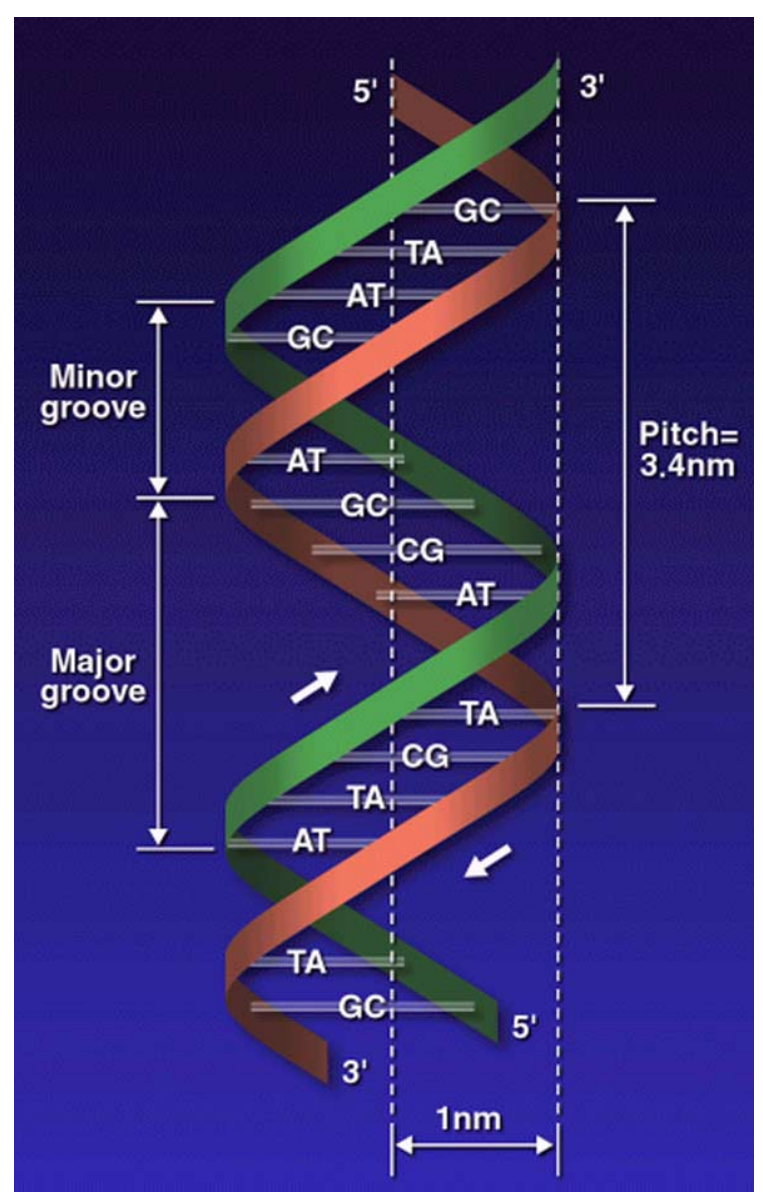

図4

虫, 植物のシロイヌナズナ, 酵母な゙でゲノムが決 まっていて, さらに, 最近, 日本人の好きなトラフ グのゲノムがほぼ決まり, マウス, ラットのゲノム 配列の研究も終わりに近づいていると言われてい るわけです。

こういうことから, 現在はポストゲノム研究の時 代に入ったと言われます。ポストゲノム研究という のは, 非常に幅広い領域を含んでいます。そのうち で重要なものを取り上げてみますと, 1つは, 遺伝 子の個人差です。人間のゲノムは 30 億の塩基対から できていて, その中でおよそ $0.1 \%$ 個人によって 違っている。すなわち, 300万か所, 我々の遺伝子 には人による違いがあるわけです。少なくともその 10分の 1 以下, 多分 20 万ぐらいが大変意味があって, それが個人差を決めているのではないかと思いま す。ということから, 1つの塩基が置きかわった SNPs (Single Nucleotide Polymorphisms) の研究が, 現在, 非常に重視されています。これによって, あ 


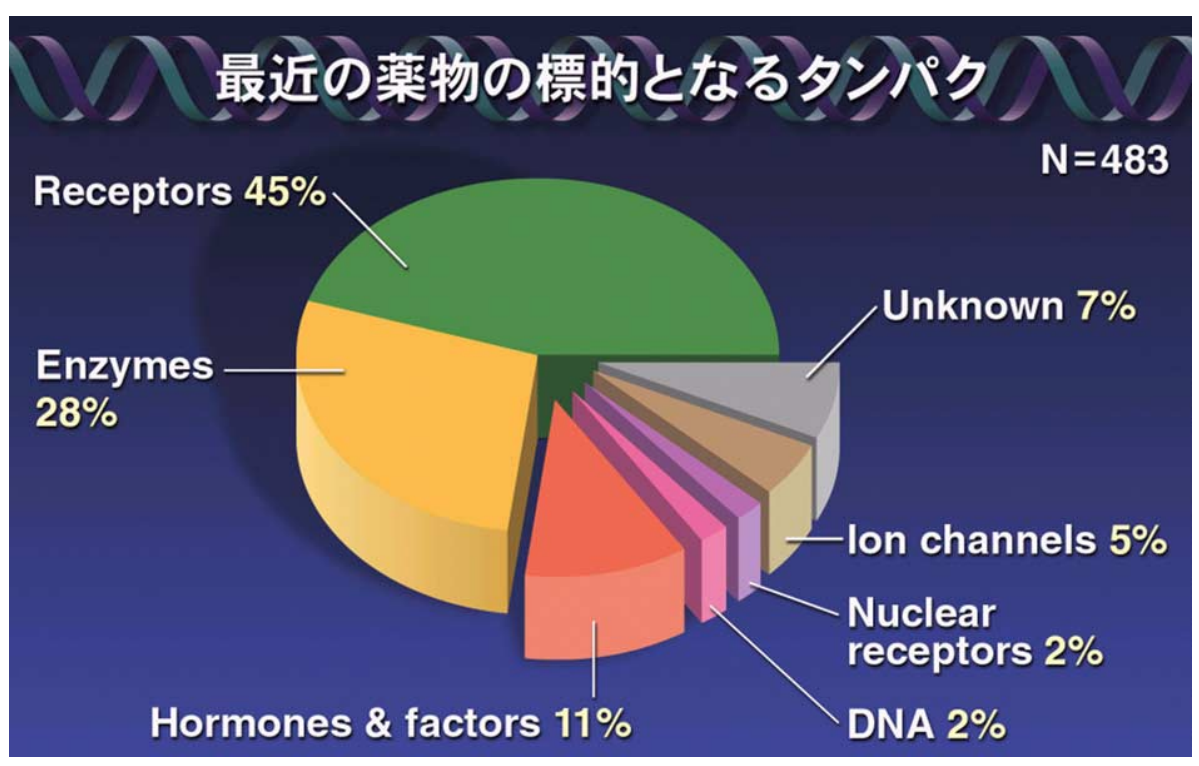

図5

る人が病気にかかりやすい, 例えば, 糖尿病になり やすいとか, 高血圧になりやすいということが決ま るわけであり, また, 薬が効くか効かないかという ことも決めることができるわけです。

\section{ポストジェノミックスの研究}

もう1つは,たんぱく（図5）の研究です。

特にたんぱくの立体構造の研究が, 新しい薬の発 見に結びつくのではないかということで注目され ています。これは2002年度の重点課題として総合科 学技術会議が選んでいるものの1つです。

立体構造が明らかになると,それに従って新しい 薬をデザインすることができるのではないかとい うことで, 非常に注目されています。

いわゆるポストジェノミックスと呼ばれる研究 が, 現在, 急速に発展しつつあります。それを受け て,これから医学が新しく発展してくるだろう。そ れによって, 先ほど申し上げたようなさまざまな高 齢者に多い疾患の対策を立てることができると同 時に, 感染症にも新たな治療方法, あるいは予防方 法を導入することができるのではないかというこ とで注目されています。

遺伝子を基礎とした研究は, 現在, 生命科学, ラ イフサイエンスの主流になりつつありますが, それ だけで医学がすべて終わるものではありません。そ れは細胞の研究が重要になるからです。個々の遺伝
子の機能がわかっても, 細胞という極めて複雑な構 造を持ったものの機能をすべて明らかにすること はできないからです。特に細胞がどのようにして作 られてきて, その機能が分化していくのか, どうい う条件で死ぬのか, どうすれば再生するのか, ある いは, どうすればがん化するのかというあたりは， 非常に大きな課題となりつつあります。

特に, 2年ほど前に, ES細胞（図6）というもの がヒトでも作られて, 急速に注目されるようになり ました。これは受精卵が発生する5日目ぐらいに肧 盤胞と呼ばれる時期があります。この時期にこれを つぶして, その内部の細胞を培養すると, ほぼ無限 に増殖する細胞が得られます。しかも, この細胞 は，条件によって神経細胞になったり，あるいは， 血液細胞になったり, 筋肉細胞になったりするわけ です。

このES細胞を使うと,さまざまな体を構成する 細胞ができて, これが, パーキンソン病の治療, 春 䯣損傷の治療, 心筋梗塞や心筋症の治療等に使える のではないかということで, 大いに注目されている わけです。

さらに, 今度は個体の生理学もまた大きな問題に なります。個体全体の発生, 成長, 生殖, 老化, 死 のメカニズム, あるいはまた, 個体の中のさまざま なシステム, 特に神経系の研究というのは, 21世紀 の重要課題で, これが最終的には人間の心をどこま で解明できるかということで, 非常に注目されてい 


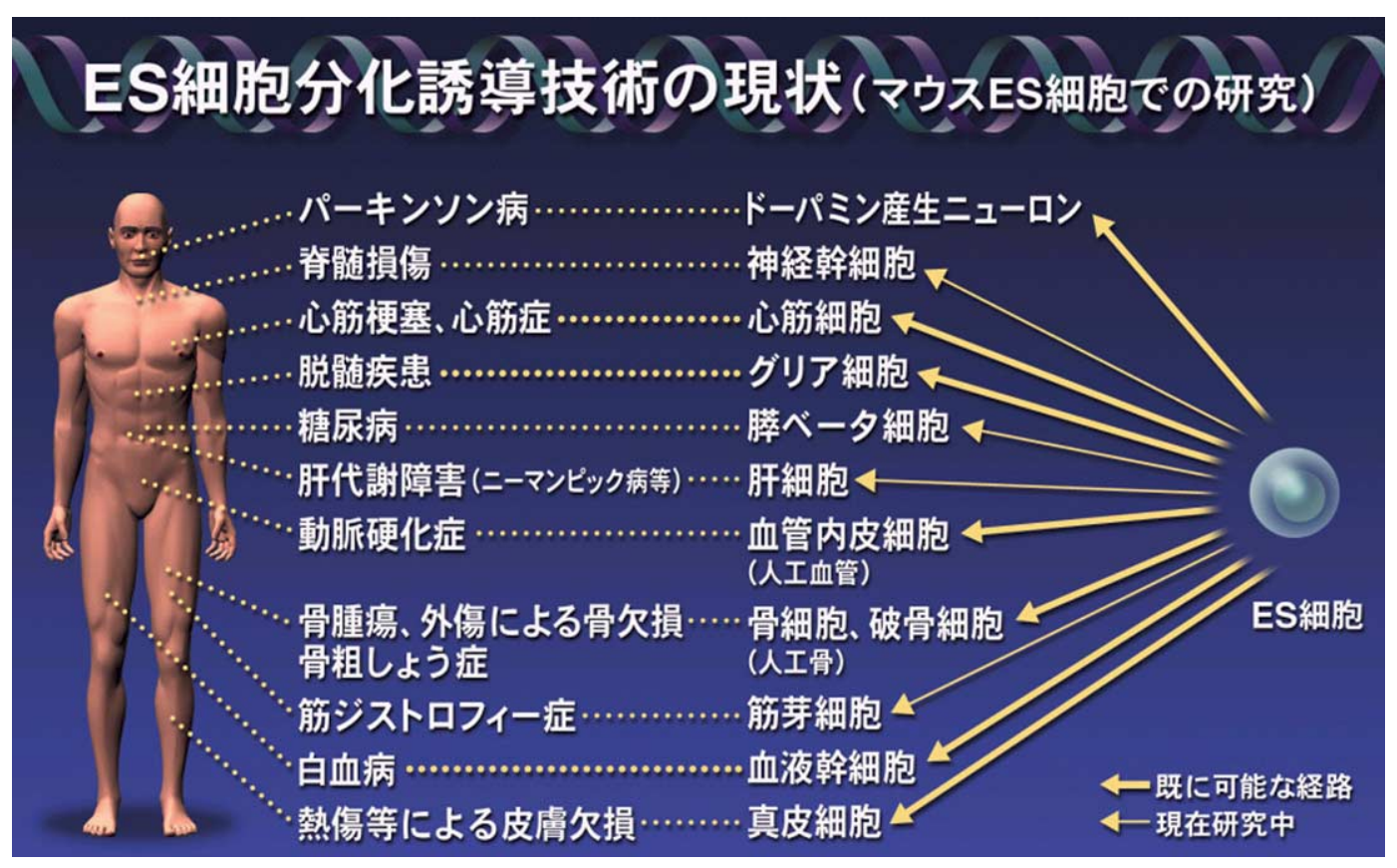

図6

るところです。

このような生命科学の研究は, 膨大な情報量を 生み出します。したがって, 従来の方法でこれを解 析することは大変難しくなります。そこで, 生物情 報学, バイオインフォマティックスというのが, こ れからの重要な研究分野になりつつあるわけです。 この分野の研究者は,わが国に非常に少ないという ことが大問題で, これも2002年度のライフサイエ ンスの重要課題の1つとして取り上げているところ です。

さらに,こういった基礎的な研究を臨床にできる だけ早く応用することによって , 患者さんの役に立 てていく必要があります。そのためには研究システ ムを改革していく。あるいは, 一般の方々の研究へ の理解と協力を得るだけでなくて, 倫理的な問題に ついても慎重に討議して考えていく必要があるの ではないかと思います。このようにライフサイエン スは, 現在, 全世界で注目されている大変重要な分 野ですので, わが国においても力を入れていきたい と思っています。

その他の分野としては, 情報通信分野がありま す。2002年度の重点課題としては, いつでもどこで も耐えられる通信技術, 融合領域一例えば, 先ほど のバイオインフォマティックス等, そして研究基 盤,この3つを取り上げています。
環境分野では, 地球環境問題, 特にグローバル ウォーミング, 温暖化が大変大きな問題で, その観 測と将来の予測, モデリングが大きい課題です。そ れから, ごみゼロにする循環型社会の構築。化学物 質のリスクの極小化と評価, 管理。自然循環および 生態系と調和する社会の構築。特に都市の環境問題 が重要です。

ナノテクノロジー・材料分野も, これから 10 年あ るいは 15 年先を見ると, 大変重要であろうというこ とで, 2002年度から重点分野として取り上げて, 次 世代半導体のようなデバイス, 環境と調和した材 料, 医学に用いられるもの, ナノバイオロジーと いってナノレベルで生命現象を研究する領域, 革新 的な機能を有する材料, 基盤技術等を取り上げてい るところです。

その他に注意すべき分野として, エネルギー, 製 造技術, 社会基盤, フロンティアを取り上げてい ます。

こうした重点政策を戦略的に進めるために, 重点 化戦略専門調査会を作りました。各省からヒアリン グをして, 重点課題を決めました。

\section{研究開発システムの改革}

もう1つの大きな政策の柱が, 科学技術システム 
の改革です。予算が過去5年間, 随分增えてきまし た。しかし, まだ日本の科学技術システムには非常 に不効率なところがあるということが言われてい ます。そのために, 研究開発システムの改革, 産官 学の連携, 地域における科学技術振興, 人材の育 成, 科学教育の改革, また, 科学技術を担当する人 たちと社会とのチャネルを構築すると同時に, 科学 者の社会的責任も問題とする。あるいは, 倫理が問 題になる。それから，いろんな基盤を整備したいと いうことで, 科学技術システム改革専門調査会で, 現在，検討しているところです。

その中で特に大きな課題が, 研究開発システムの 改革です。すなわち, わが国では競争的な研究開発 環境が,アメリカ, イギリスに比べて劣っていると いうことで,もっとコンペティティブになるように しないといけない。そのためには, 任期制を導入し たり，あるいは，若手研究者を支援することによっ て, 若い人たちが活発に研究できるようにするべき であろう。それから, 評価システムを改革する。さ らに, 制度の弾力的運用をしていく。と同時に, 産 学協力を推進することが必要になってきます。

わが国では産学連携が従来進まなかったわけで すが, それにはいくつかの理由があります。

1つは, 大学側で, 大学の先生が産学協力に余り 関心がなかった。すなわち，論文重視であったとい うこと。それから, 連携のための組織がなかった。
一方，企業のほうは，従来は自前主義であった。 それから, 大学のレベルの高い研究を見きわめる努 力をしてこなかった。

それから, 大学と企業のインタフェースになる部 分（図7）が, わが国では大きく欠落していた。例 えば, ベンチャーがなかった。インキュベーターが 非常に少なかった。それから, 産学官を結ぶ人材, コーディネーターのような人がいなかったという ことがあります。

そこで, これを改革するためには, 大学, 企業と それぞれのレベルでやっていく必要がある。

企業側としては, 大学との人材交流を積極的に進 めるべきである。そ扎から, 委託研究制度の活用を しないといけない。さらに, ベンチャーのスタート アップの支援, TLOの設置促進, インキュベーター の育成などが大きな問題になっています。

政府·自治体は, こういった大学, 企業, インタ フェースに対して, 支援をしていく必要があるわけ で, 2002年度から振興調整費でマッチングファンド を始めます。また, 私立大学の研究開発機能の支援 も行っていく予定です。

知的クラスター（図8）も，2002年の重要課題の 1つです。全国に新しい科学技術に基づく産業を生 み出すためのクラスターを作っていこうというの が1つの大きな政策になっています。

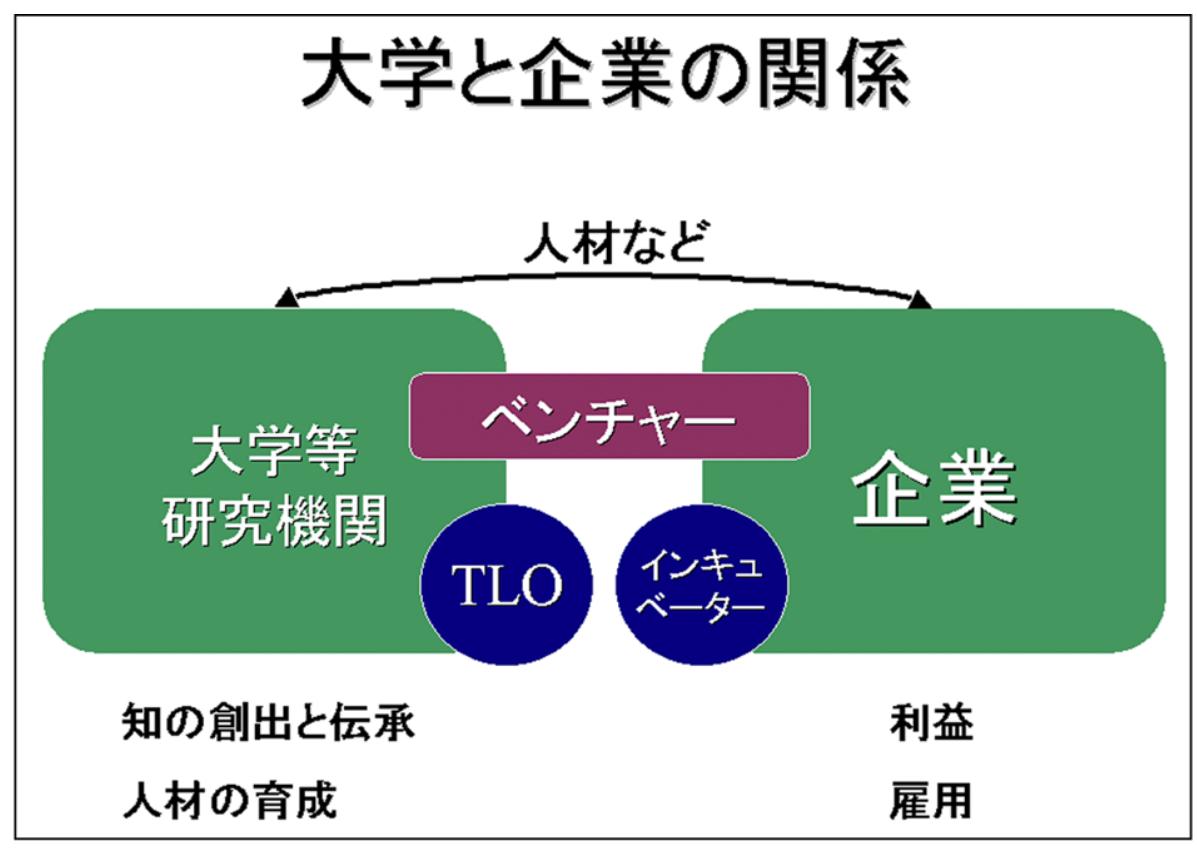

図7 


\section{知的クラスター(Sophiopolis)}

\section{ある分野の研究機関、ベンチャー、企業な どが、一定の地理的範囲に集中して存在 し、相互に関係をもったもの}

\author{
特徴 \\ 知(Knowledge)の共有と交流(知的空間) \\ 競争と協力による相互刺激 \\ 実質的な研究規模の拡大(相補性) \\ 研究所、材料供給者へのアクセス \\ 公的支援(インフラ整備) \\ 新ビジネスの機会
}

図8

\section{自由な発想による研究を}

最後に,これからのわが国の科学技術政策にとつ て重要なことを, いくつかまとめます。

まず最初は, 研究者の自由な発想による研究を尊 重することです。すべてを目的型にしたのでは，日 本の研究は窒息してしまう。必ず研究者が自由な発 想でする研究に研究費を配分すべきです。

しかし, プロジェクト型の研究は思い切って重点 化しないといけない。一例を挙げると, ヒトゲノム の研究があります。日本もアメリカと余り変わらな い時期に研究を始めようとしました。しかし,うま
く組織が作れなかったわけで, 理化学研究所がヒト ゲノムのセンターを作って始めたのは，2,3年，ア メリカやイギリスに後れてしまった。その後れが最 終的に十分な貢献ができなかった理由になってい ます。すなわち, プロジェクト型は思い切って重点 化して, しかも, 短期間にお金を十分つぎ込んでい くということが重要です。

それから, 何といっても, 若い研究者を育てる, これが非常に重要です。わが国の自然科学者でノー ベル賞を受賞された方が,ノーベル賞の対象となっ た研究をいつ始められたかというのを調べてみる と, すべて40歳以下です。わが国は, 従来, こう いった極めて創造的な時期の研究者を, わが国のシ ステムが悪いためにつぶしてきたんじゃないかと いうことが考えられるので,これをぜひ考えていく 必要があります。

それから，国際的な競争力がないとだめです。国 際的に出して十分競争力を持った科学技術を育て ていく必要があります。

それから, システムの改革。これは大学, 研究 機関などいろんなシステムを変えていかないとい けない。そのために重要なのは, 速度です。わが 国の改革の最大の問題点は, 速度が遅いというこ とです。

最後に, 教育です。教育にとって最も重要なの は, 科学への情熱ではないか。これをどのようにし て若い人に植えつけていくのかというのが, これか らの最大の課題だろうと思います。 